\title{
The Accretional Beach Ridge System of Tongoy Bay: An Example of a Regressive Barrier Developed in the Semiarid Region of Chile
}

\author{
María-Victoria Soto ${ }^{1 *}$, Joselyn Arriagada ${ }^{1}$ and Misael Cabello ${ }^{2}$ \\ ${ }^{1}$ Department of Geography, University of Chile, Chile
}

${ }^{2}$ Physical Geography Lab, Department of Geography, University of Chile, Chile

Submission: January 19, 2018; Published: February 20, 2018

*Corresponding author: María-Victoria Soto, Department of Geography, University of Chile, Santiago, Chile .Email : mvsoto@uchilefau.cl

\begin{abstract}
The regressive barrier (strandplain) of Tongoy is a complex system of coastal landforms, composed of foredunes, beach ridges and semipermanent streams that together have shaped the actual lagoons. This research aims to contribute to the knowledge of these features in the tectonic active western continental margin of South America and analyzes their evolution in the development of the regressive barrier of Tongoy Bay. A geomorphological survey was conducted, between the Pleistocene marine terraces and the modern shoreline; aerial photographs from different years were used, observing changes over the barrier surface, estuaries and lagoons. From the identified forms it is concluded that the barrier corresponds to an accretion system, which together with the development of beach ridges has evolved into a regressive barrier system. It is still possible to find abandoned lagoons behind the present lagoons. Currently, accretion conditions are demonstrated by the preservation of foredunes and embryonic dunes.
\end{abstract}

Keywords : Beach ridge; Barrier; Foredunes; Lagoon

\section{Introduction}

Traditional costal barriers have been studied as characteristic features of drilling coasts, with a major territorial expression on the east coast of South and North America, Australia, South Africa, and Western Europe [1,2]. Costal barriers of Brazil are highlighted in South America, described by Dillenburg \& Hesp [3], Hesp et al. [4]. Dillenburg et al. [5].

In Chile, these forms have been analyzed as coastlines formed by beach ridges [6,7]. We approach the subject from the conceptualization of the strandplain in coastal barriers on a continental subduction margin, as in the case of Chile.

Regarding the systems to be described, the presence of beach ridges is an essential feature, and has been considered according to Otvos'definition [8], that is to say, there are a relict, semi parallel, multiple ridges forming a strandplain. Tamura (2012) indicates the relevance of beach ridges as a pale environmental record, which is of great significance for the analysis of Tongoy Bay.

Regressive barriers such as morphological systems correspond to a modern feature associated with the last postglacial marine transgression and marine processes related to conditions of sediment supply, and processes of progradation during the last 7 to $6 \mathrm{ky}$, according to Dillenburg \& Hesp [3].
They conclude that the morphology and structure of regressive barriers are very diverse, with various forms of sub aerial origin: foredunes, beach ridges, and complex dunes.

In the arid coast of Chile, in the Atacama desert (Caldera, $27^{\circ} \mathrm{S}$ ), there are important Pleistocene beach ridge sequences, described by Marquard et al. [9] and Quezada et al. [10] as paleo beaches located on marine terraces; the age of these terraces are estimated to be between MIS 11 and MIS 5 c, with \pm 162 to \pm 25 meters height. In Punta de Choros ( $\left.29^{\circ} \mathrm{S}\right)$, at the north end of the mega bay of Coquimbo, beach ridges are also located on Pleistocene marine terraces [11], as well as slightly covered by dunes, located at 70 meters height. In the case of the coast of Chile, the tectonic condition is an imperative agent of landscape modeling, responsible for the presence of marine terraces preserved at high altitudes.

Concerning the Holocene coastal barriers in the Chilean semiarid region, Paskoff [12] described the succession of beach ridges in the Bay of Coquimbo $30^{\circ} \mathrm{S}$. [13] mapped and dated back the Holocene beach ridges in Tongoy Bay, with dates of 5400 yrs BP for the oldest ridge located along the escarp of the Pleistocene terrace, and 910 yrs BP for the latest (they are noncalibrated ${ }^{14} \mathrm{C}$ datings). The strandplain of Tongoy extends from the modern berm to the escarp of the marine terrace at $900 \mathrm{~m}$, 
with a progradation speed estimated as $0.13-0.14 \mathrm{~m} / \mathrm{y}$ by Ota and Paskoff [13].

The presence of abandoned and modern lagoons in the barrier of Tongoy, associated with river outlets is a morphogenetic aspect to be considered when studying environmental conditions Geological and Geomorphological Settings during the development of the barrier. The barrier of Tongoy is analyzed from the point of view of its conformation as a coastal system in an environment of tectonic uplift, in order to establish its current condition and evolutionary trends associated with the status of erosion/progradation in the Chilean semiarid region.

Table 1: Tectonically uplifted levels of marine terraces according to different authors for the area of study.

\begin{tabular}{|c|c|c|c|c|c|c|}
\hline \multicolumn{2}{|c|}{$\begin{array}{l}\text { Identified Marine Terraces On The } \\
\text { Area Of Study }\end{array}$} & \multicolumn{2}{|c|}{ Pfeiffer (2011) } & \multicolumn{3}{|c|}{ Saillard et al.[18] } \\
\hline Pfeiffer (2011) & Paskoff (1970) & Age (Ky) & MIS & Age & MIS & $\begin{array}{l}\text { Rate Of Rise (Mm/ } \\
\text { Ka) }\end{array}$ \\
\hline Terrace I & Sereniense I & - & - & $679 \pm 51$ & 17 & $738 \pm 151$ \\
\hline Terrace II & Sereniense II & $\begin{array}{c}412 \\
\text { (Late Pliocene- } \\
\text { Pleistocene) } \\
\end{array}$ & 11 & $318 \pm 30$ & $9 \mathrm{c}$ & $1158 \pm 411$ \\
\hline Terrace III & Herraduriense I & $\begin{array}{c}225 \\
\text { (Middle } \\
\text { Pleistocene) }\end{array}$ & $7 e$ & $225 \pm 17$ & 7 e & $389 \pm 149$ \\
\hline Terrace IV & Herraduriense II & $\begin{array}{l}\text { 123(Upper } \\
\text { Pleistocene) }\end{array}$ & $5 e$ & $149 \pm 10$ & $5 e$ & $180 \pm 80$ \\
\hline Terrace V & Veguiense & 6 (Holocene) & 1 & $11 \pm 2$ & 1 & - \\
\hline
\end{tabular}

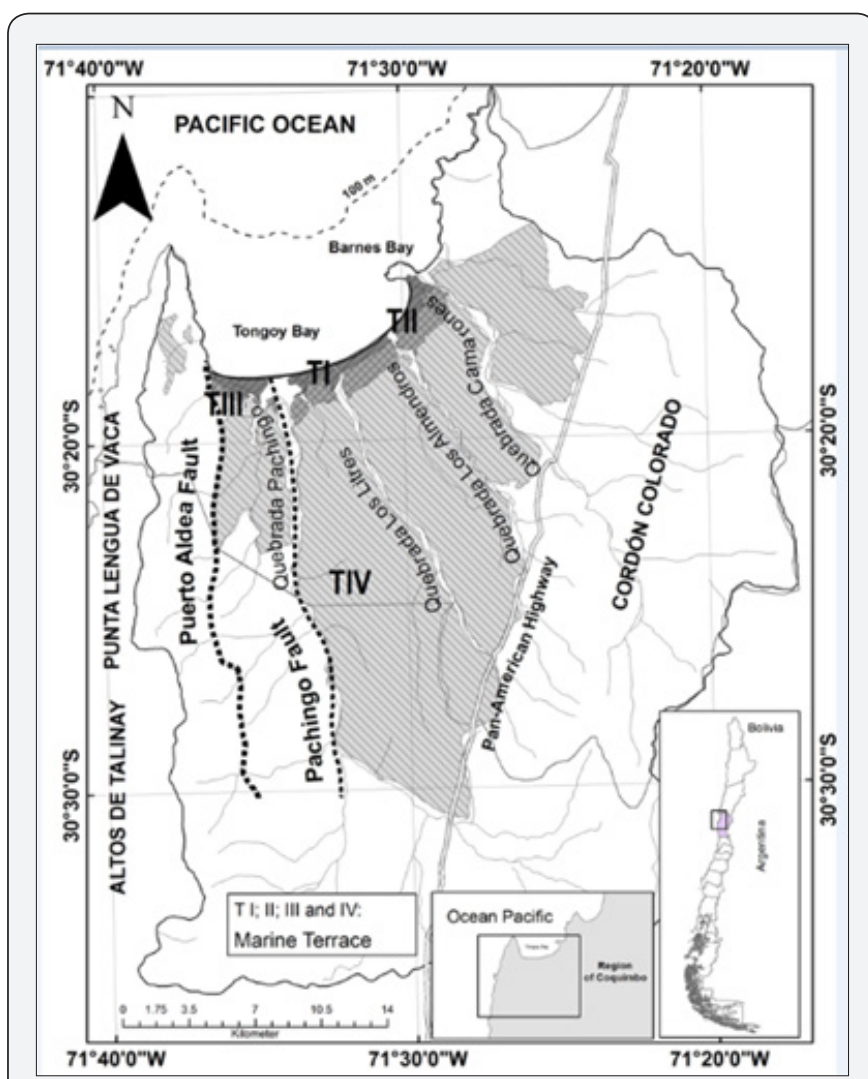

Figure 1 : Location of Tongoy Bay in the semiarid region of Chile. There are four upraised marine terraces $[14,16]$. The extensive and high headland of Altos de Talinay, belongs to costal range of The Andes is the essential relief that explains the dynamics of the bay.
According to Le Roux et al. [15] these marine sediments/ terraces were formed by a series of transgressions/regressions, which were related to regional and local tectonic movements, combined with global sea level variations [12,16-18]. Saillard et al. [18] confirmed the tectonic influence on Tongoy Bay through U-Th dating of beach ridges of these uplifted marine terraces, concluding that there has been a differential evolution between the bay and the associated great headland (Punta Lengua de Vaca) as well as the Puerto Aldea fault (Figure 1; Table 1). Therefore, influences on the genesis of the paleo basin, as well as current hydrodynamic conditions in Tongoy Bay are conditioned by the presence of the great headland of Punta Lengua de Vaca (Figure 1).

\section{Semiarid Coastal Climate}

The Pacific anticyclone strongly affects the climate of Chile and the Region of Coquimbo, generating inversion processes along the northern coast, resulting in the retention of permanent cloud strata throughout the year, which is hundreds of feet high, blocking frontal systems and thus explaining the arid climate [19]. These are a transition between the desert and semiarid Mediterranean climate. The coastal zone is a steppe climate with abundant cloudiness, characterized by high humidity (85\%), with a moderate temperature regimen and temperature variation not exceeding $6^{\circ} \mathrm{C}$ and an annual temperature average of $14.7^{\circ} \mathrm{C}$; precipitation is concentrated in winter months (May to August) and does not exceed $75 \mathrm{~mm}$ per year [19].

The area is affected by El Niño (ENSO), which last occurred in 1997, and is considered the strongest of the last century 
$[20,21]$. On that occasion, heavy rainfall and severe flooding occurred during winter and spring in central Chile; there was an annual total of $190 \mathrm{~mm}$ in the Region of Coquimbo, with $50 \%$ concentrated in a few days. Furthermore, during the El Niño event of 1983 there was a precipitation of $116 \mathrm{~mm}$ within 3 days of July (data from Dirección Meteorológica de Chile).

Prevailing winds are from the S and SW, associated with a condition of littoral drift from south to north. There are very few incidents of northerly winds throughout the year. However, they mainly occur during winter months and transport warm waters into the bay [22].

\section{General Oceanographic Characteristic}

The area of study corresponds to a quite depopulated coastal area of the Chilean semiarid region, which has a small holiday village in the northern part of the bay, and fishing creek in the southern part. This has effects on the absence of oceanographic data for the area, where the existing information is concentrated in the port of Coquimbo, 35 miles north. It may be generally noted that the area has a semidiurnal tidal regime in a micro tidal environment with a maximum-recorded plea of $1.8 \mathrm{~m}$. The wave height measurements performed in this study revealed waves ranging from about 0.5 to $1 \mathrm{~m}$, especially in the middle and distal part of the bay. According to data provided by a station located in Tongoy Bay, $32 \%$ of the prevailing winds in the area are from South $(\mathrm{S})$ with a predominant speed of 1.6 to $1.4 \mathrm{~m} / \mathrm{s}$.

There is no bathymetric detail for Tongoy Bay; however, the work of Berrios [23] indicates the presence of bathymetric slopes ranging from $2.7^{\circ}-4.0^{\circ}$ in central areas and $8.9^{\circ}-13.3^{\circ}$ in lateral areas.

\section{Methods}

Photo interpretation was conducted with aerial photos from the Aero Photogrammetric Service, for the years 1978 and 1997. Fieldwork was conducted in two stages: the first during the months of May, July and December 2012, and the second stage in February and July 2013.

The littoral zone was analyzed according to the classification of wave-dominated beaches of Araya-Vergara (1996); Short (1999); Wright and Short (1984). Mapping of the bay with Google Earth images was performed considering 5 different years between 2001 and 2010, which was supplemented with field observations from June 2012 to February 2013.

Beach ridges were identified from the work of Ota and Paskoff [13]. A topographic survey was developed considering a total station (February 2013), performing transverse profiles, with approximately $1,000 \mathrm{~m}$ spaced, as well as tracked from the swash zone to the escarpment of the Pleistocene terrace.

Foredunes and transverse dunes were identified in the field and in aerial and Google Earth images, and then represented in a geomorphological chart. Foredunes were considered as an indicator of wave dynamics, sand supply, and current barrier accretion. In this context, incipient dunes were considered according to Hesp [24]. Transverse dunes were only identified with aerial photos from 1978, because of recognition difficulties due to current desertification control techniques through diverse plantations. The relationship between these dunes was seen according to the notion of dune continuum of Araya-Vergara [6], in Arriagada [25] and Verstapen [26].

Fluvial forms were analyzed through the identification of channels and riverbanks from photo interpretation and fieldwork. Tricart's concepts (1960) were applied, distinguishing levels of Holocenic terraces, $\mathrm{T}^{\prime}$ and $\mathrm{T}^{\circ}$. These terraces were identified in the barrier of Tongoy, establishing different progradation sequences. Riverbanks were analyzed according to Arriagada [25] as evolution indicators of watercourses that flow into the barrier and those which genetically associate with small existing lagoons.

\section{Result}

The physical characteristics of Tongoy Bay, and its location in relation to both the headland and coastal ranges of The Andes, together with the low tidal range and semiarid climate, play a key role in the evolution of the stand plain analyzed. The Tongoy barrier presents several kinds of features that have been developing since Holocene until the present day, mainly through the growth of foredunes in a low energy reflective beach.

\section{The Littoral Zone}

The analysis results of wave-dominated beaches allows to establish the presence of clear spatial and temporal patterns associated with the predominance of reflective beaches, except for several local situations, as in the northern section: Low Tide Terrace (LTT). Even though the results of Figure 2 do not correspond to a systematic observation over time, fieldwork in both winter and summer allow validation of them as a pattern, since low energy conditions of reflective beaches are observable during different seasons, due to the stable climatic conditions of semiarid coastal Chile. The exception is during ENSO years when abundant and concentrated rainfall occurs.

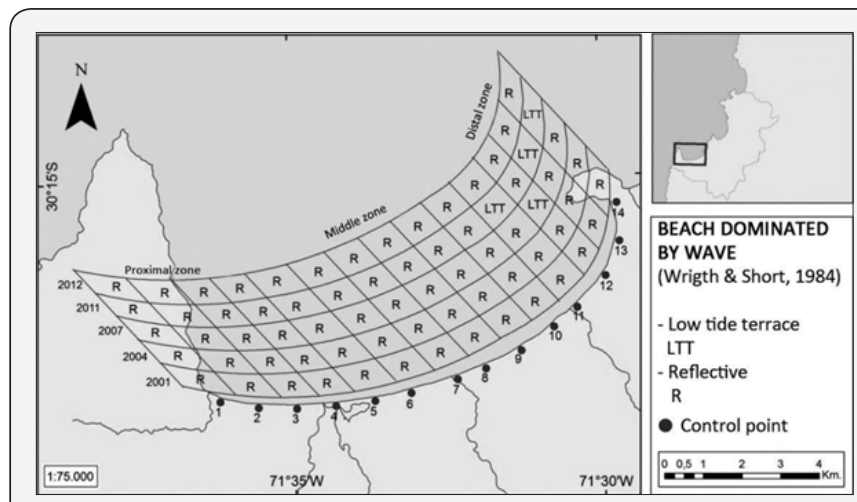

Figure 2: Beaches dominated by waves in Tongoy Bay, showing the dominance of the reflective beach during 5 different years observed, associated with the extensive headland in the southern part of the bay. 


\section{Recent Advances in Petrochemical Science}

The homogeneous distribution of reflective beaches is associated with the presence of the great headland of Punta Lengua de Vaca (Figure 1) which is so extensive that it exerts strong control on the wave refraction along the bay. Pattern changes are only seen in northern Tongoy, with intermediate conditions. The dissipative condition has never been observed.

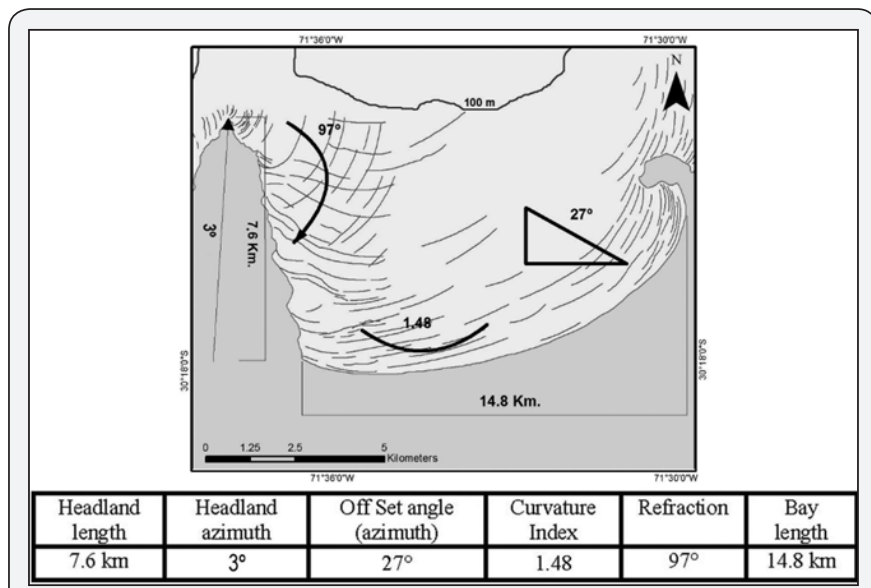

Figure 3: Morphometric parameters of Tongoy Bay, highlighting the prominent headland and its influence on the refraction waves from the SW, which lose their high energy and reach the beach as little plunging waves $(1-0.5 \mathrm{~m})$.

Figure 3 express some basic morphometric parameters of the bay associated with the presence of the headland, with N/S orientation, and $7.6 \mathrm{~km}$ of extension forming a natural barrier to the prevailing SW winds and associated wave trains. The extensive headland generates very strong refraction waves from the SW, and when they reach the coastline, the energy is dissipated creating a very reflective beach, with break waves of less $1 \mathrm{~m}$.

Considering the Triassic genesis of the headland, the Miocene-Pliocene genesis of the upraised marine terraces, and the strandplain progradation during the Holocene, it can be derived that similar wave currents have been in operation for much of the evolutionary history of the bay.

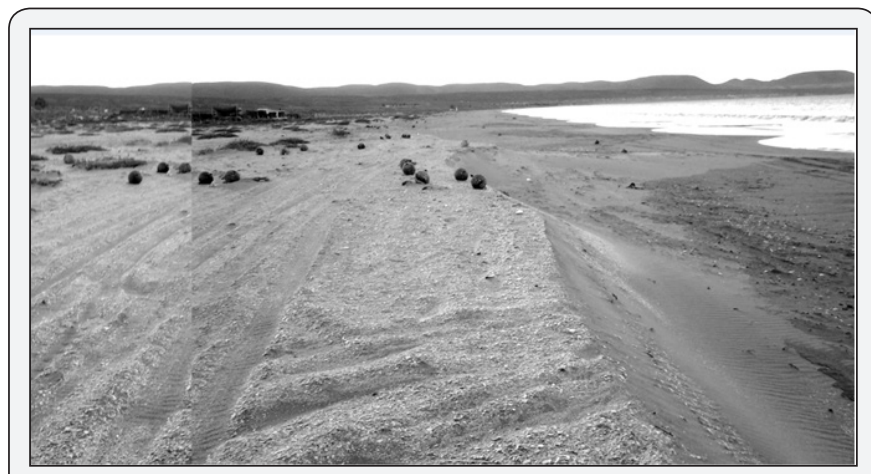

Figure 4: Eroded beach cusps and incipient dunes (small-vegetated nebcas). Reflective beach, southern Tongoy Bay (February 2013).

The wave attack condition is important on the beach and berm, which are eroded during winter storms, but are quickly rebuilt, indicating a positive mass balance of the beach through the reconstruction of the berm and the presence of incipient dunes, as observed during the period of May 2012 to February 2013, winter-spring seasons 2015 and 2017. The presence of beach cusps in the bay, especially in the middle and northern areas is another antecedent denoting the wave attack condition (Figure 4).

The foredunes are a permanent feature along the bay, but are not uniform in shape; the southern and middle areas comprise up to three ridges of discontinuous vegetated nebcas, always with minor incipient dunes. In the distal zone, foredune ridges are very active, always with incipient dunes developing rapidly, even after being attacked by waves (Figure 5). The generation of incipient dunes is very fast and is mainly associated with vegetation, Ambrossia chamissonis in this case, a creeping kind of plants with wide coverage in Central Chile up to $30^{\circ} \mathrm{S}$ of northern limit.

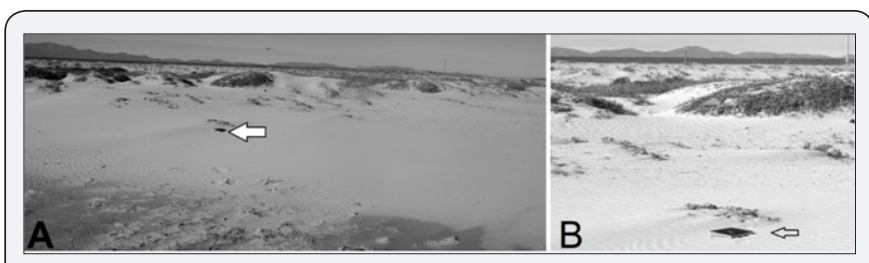

Figure 5 : Northern foredunes in Tongoy Bay, with evidence of recent wave attack (A). Small sized incipient dunes, as seen in the ripples to leeward of the reference scale (notebook of $22 \mathrm{~cm}$ length), during fieldtrip observation (B). (May 2012).

\section{Beach Ridges}

Ota \& Paskoff [13] identified five ridges in the southern section of the bay, which can hardly be recognized today. Beach ridges correspond to soft sand undulations. The aforementioned author's descriptions indicated the presence of abundant remains of shell fragments and gravel on the beach ridges, which were only possible to find in the middle and proximal part of the bay. At the same time, the strandplain is covered with Atriplex, which has masked the original features.

Beach ridges are located immediately below the escarpment of the terrace, with the southern section presenting a broader strandplain of $900 \mathrm{~m}$, measured from the swash zone to the base of the escarpment of the marine terrace (Profile 2, Figure 6).

The oldest beach ridge is well preserved, just like the latest, which is located close to the modern foredune system. The following sequence is observed in the distal and middle areas of the bay:

a) Beach face and sandy beach

b) foredunes and incipient dunes

c) marshes

d) Beach ridge

This sequence measures up to $150 \mathrm{~m}$ long (Profile 11, Figure 6). The marsh shows a maximum width of about $20 \mathrm{~m}$, being a well-represented feature in the bay due to the presence of 
a water table, as well as the evergreen vegetation that exists due to the occasional drainage from the ravines that dissect the adjacent marine terraces. The cloudiness and coastal fog of the Chilean desert (camanchaca), contributes to the maintenance of existing marsh vegetation in these depressions.

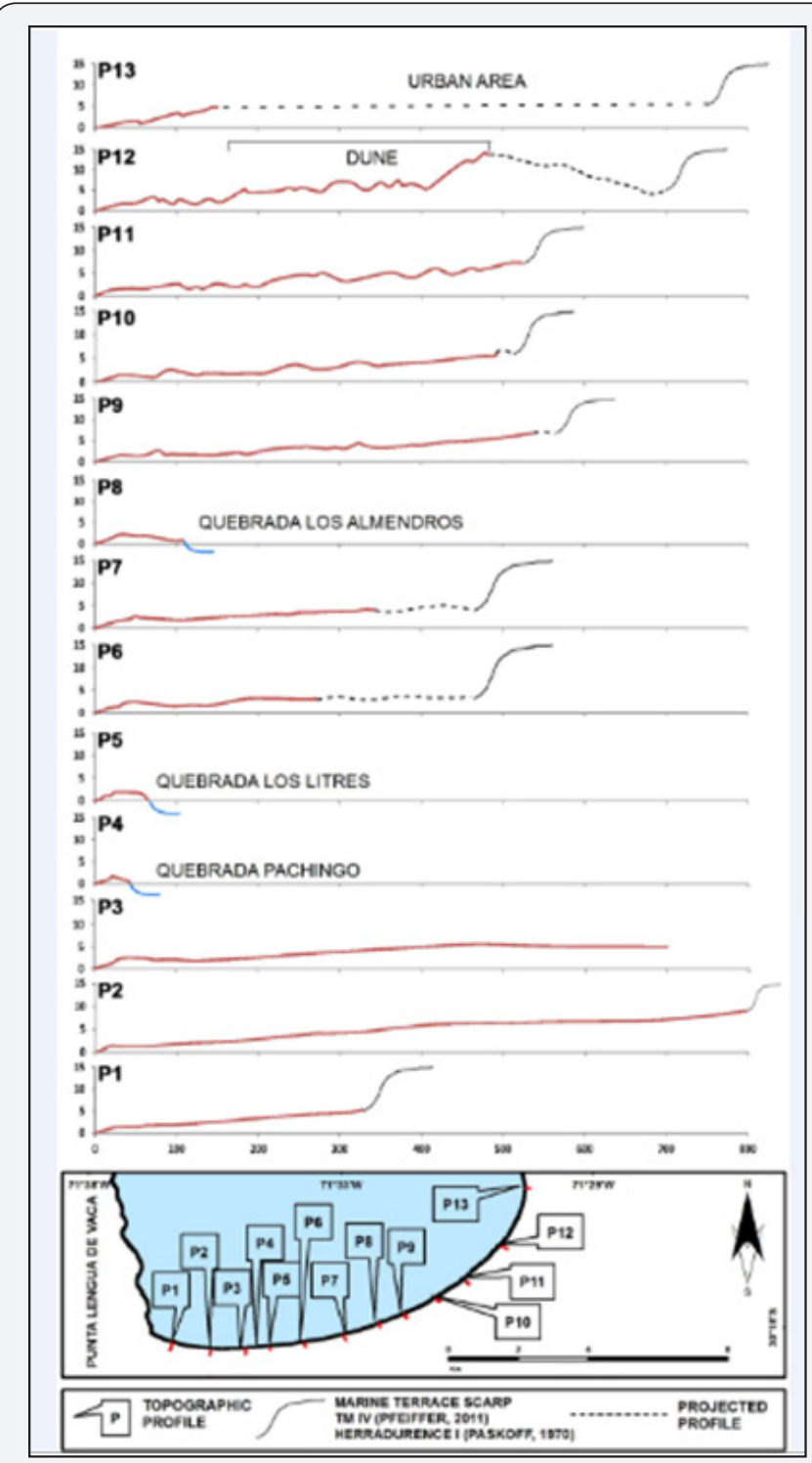

Figure 6 : Transverse topographic beach profiles in Tongoy Bay, showing the differences along the shoreline, such as the length from swash zone to marine terrace scarp.

Beach ridge sequences are most representative in the middle area (Profile $9 \& 10$, Figure 6), because the wind mantle is not as developed as in the north, where the beach ridges are covered by dunes (Profile 12, Figure 6). In fact, the observed peaks correspond to large active dunes in which the desert scrub vegetation has disturbed the patterns of transverse dunes that cover the beach ridges. Despite this current dynamic condition, it is possible to recognize evidence of beach ridges along the bay at $50 \mathrm{~m}, 200-250 \mathrm{~m}$ and $400-500 \mathrm{~m}$ away from the beach. In the case of the first ridge, sandy beach and foredunes are included.

\section{Fluvial and Hydrological Features}

Local watersheds that drain into Tongoy Bay have generated essential features through which it is possible to establish environmental variations of the shoreline. The tectonic influence is expressed through epigenic incised gorges in ancient marine terraces, forming broad valleys of $353 \mathrm{~m}$ and an incision height up to $192 \mathrm{~m}$ (Quebrada Pachingo). In these valleys, Holocene fluvial terraces have been formed, identified as $\mathrm{T}^{\prime}$ and $\mathrm{T}^{\circ}$ (Figure 7). The $\mathrm{T}^{\prime}$ terrace is a well preserved unit, consisting of sands and gravel, located at the foot of the escarpment of the Pleistocene terrace next to the river outlet, adopting the form of a well-developed river bank. The $\mathrm{T}^{\circ}$ terrace is the present riverbed with seasonal behavior, which is activated by episodic rainfall events, such as during El Niño years.

The identification of river terraces $\mathrm{T}^{\circ}$ and $\mathrm{T}^{\prime}$ in different positions in the strandplain, allowed the establishment the presence of differentiated lagoons conditions, determining three evolution pulses of the coastline and river outlets, associated with the lagoons (Figure 7). The paleo lagoon (1) and (2), as well the present day lagoon (3), whose barrier has been closed since 1978 preventing drainage to the bay (as recorded by aerial photos). However, according to data compiled by locals, in 1997 the river outlet was open due to heavy rainfall; the most intense El Niño event of the last century was recorded in Chile that year [20], generating a great impact in central Chile and in the semiarid region, with heavy rainfall and associated flooding $[27,28]$.

Features associated with the paleo lagoons allow differentiation of evolutionary states of the river outlets located in the strandplain accretion environments (Figure 7). The $\mathrm{T}^{\prime}$ and $\mathrm{T}^{\circ}$ terrace system corresponding to the (1) condition represents the river outlet of Quebrada Pachingo (see Figure 1 for location), which is correlated with the oldest beach ridge, expressing a fluvial environment with a direct outlet to the sea and capable of modeling a meandering channel. This outlet also drained three lateral tributaries, with embedded meanders and disfluencies that explain the amplitude of the sea outlet in the stage (1).

There is a second river outlet associated with lagoons, denominated as (2), identified by the channels of the $\mathrm{T}^{\prime}$ terrace as well as the remaining riverbanks; which is a strandplain with a second progradation stage associated with second beach ridge.

The (3) condition corresponds to current lagoons which are closed to the sea and have inlet episodic character associated with river flooding and storm conditions due to El Niño. The beach ridge that closes the existing outlets of the strandplain has similar dimensions along the bay, in the order of $50-100 \mathrm{~m}$ (Figure 6).

From the point of view of evolution and present changing trends, a progradational trend can be established, associated with the development of embryonic dunes and foredunes, despite winter erosion and the reflective beach controlled by 


\section{Recent Advances in Petrochemical Science}

the huge headland. These features developed in 1-3 ridges, and the embryonic dunes rapidly develop in the beach face and backshore of the barrier of Tongoy. Wind coverage in the area of beach ridges located in the distal area, expresses the status of permanent sand supply.

\section{Discussion}

The identified features in Tongoy Bay show a sequence of coastal progradation during the Holocene in an abrasion platform identified by Pfeiffer et al. [16]. Saillad et al. [18] identified the structural links between the paleo bay from Tongoy to Altos de Talinay and Punta Lengua de Vaca. Lagos [29] and Villagran [30] point out the importance of this rocky ledge and how the headland affects the current dynamics of Tongoy Bay. While tectonic action is very marked in the region, it has been quite low since the Holocene, with an uplift of $0.13-0.14 \mathrm{~m} / \mathrm{ky}$ [13].
Saillard et al. $[17,18]$ estimated an uplift rate of $1667 \pm 434 \mathrm{~mm} /$ ka for Tongoy, from the Middle Holocene to the present. Encinas et al. [31] estimated an uplift of (6645 yr BP) at $0.4 \mathrm{~m} / \mathrm{ky}$, in the Holocene marine layer on the coast of central Chile ( $\left.33^{\circ} \mathrm{S}\right)$.

The interpretation of the evolution and conformation of the barrier of Tongoy, is associated with the first beach ridge, identified by Ota \& Paskoff [13] with an age of 5400BP. Identified fluvial forms indicate that a system of river outlets of large amplitude was developed over time, such as the extension of $\mathrm{T}^{\prime}$ and $\mathrm{T}^{\circ}$ terraces of the (1) state, in the Quebrada Pachingo (Figure 7). The environment conditions indicate a major fluvial flow in the local watercourses, which has shaped the beds of distal tributaries that drained directly into the strandplain. The (1) condition is only found in the proximal part of the bay, where the barrier is larger with $800 \mathrm{~m}$ wide.

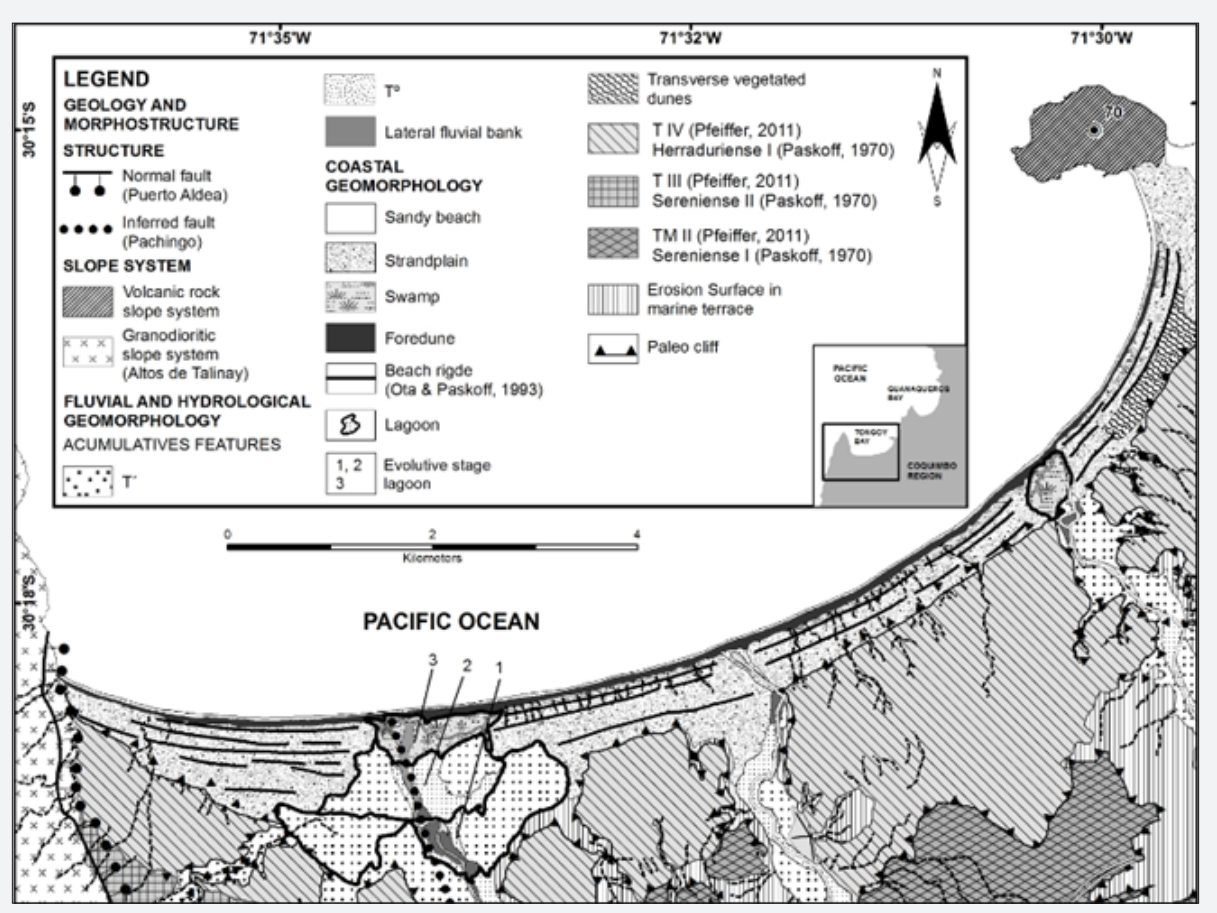

Figure 7: Geomorphological map of the Tongoy barrier: strandplain and the beach ridges and present foredunes. The different lagoons associated with the inlet streams from local catchments, as well as the 3 evolutive stage lagoons related to the regressive barrier.

However, the (2) condition is recognizable across the barrier of Tongoy through the paleo lagoon 2 and the transverse dunes isolated from the distal part. Thus, when the second beach ridge was developed in the southern area, a new outlet was formed, which is represented by deposits in $\mathrm{T}^{\prime}$ and $\mathrm{T}^{\circ}$.

Moreover, rivers would have closed up to the sea when the marshes depression occurred, associated to the last beach ridge, namely 910 yrs BP. In the northern area, transverse dunes are deposited, showing a significant sediment load. However, these sand dunes are unable to reach the scarp of the Pleistocene marine terrace. Currently, these dunes are disconnected from the present beach. The second ridge has a height of $3.83 \mathrm{~m}$ with a distance of $270.40 \mathrm{~m}$. to the swash zone. Further south, the correlative ridge to the lagoon has similar values with a height of $3.37 \mathrm{~m}$ and a distance of $223.26 \mathrm{~m}$.

The arrangement of the north-distal dunes matches with the headland bay beaches theory in Chile, that has been described by Araya-Vergara [32]; Arriagada [25]; Arriagada, Soto \& Sarricolea [33]; Martínez [34]; Soto [35]; Soto and Arriagada [36]. In central Chile, the shoreline is controlled by the structure of the continental margin and together with the SW drift generates the different dynamic conditions in the sandy beaches, associate with reflective environment in the proximal part of the bay (southern), and in the distal one (northern) it is possible to find the widest coastal sand dunes. In Tongoy Bay, the small field sand dunes are located in the northern part. 
As for the observed beach dynamics, there is evidence of an appropriate condition for sand supply. Foredunes eroded by wave action are permanently reconstructed in all seasons as documented by Lagos [29] and Soto et al. [33]. In the middle and mainly in the distal area, the sand supply condition is more pronounced, as the foredunes are more prominent. These are not considered old foredunes, because they consist of sand that has been deposited due to introduced vegetation. The foredunes are associated with sand aspersions in the same location. However, there is no connection between these and the current beach dunes because they are separated by two beach ridges.

The evolution of the strandplain, as a succession of beach ridges, with fluvial features, dunes, and different stages of the berm, identifies the system as an accretionary barrier, with a modern progradational evolutionary trend, evidenced by the dynamics of foredunes and embryonic dunes on the current beach, as noted by Dillenburg \& Hesp [3] and Soto et al. [37].

While there is no pale climatic data for validating the found morphological evidence, the works of Tamura [38] and Nielsen et al. [39] area ratified, in regard to the importance of beach ridges as paleo environmental record [40-44].

\section{Conclusion}

Identified features such as beach ridge sequences with beach gravel, foredunes, and lagoons associated with local river outlets, together constitute morphological characteristic elements associated with the coastal barrier environment of Tongoy Bay. Riverbeds and riverbanks are outlet environments that correlate to the progradation of the barrier. The accretion of the barrier through beach ridges seems to have developed the existing marsh area in the river outlet, which is currently closed by the barrier.

Foredunes and embryonic dunes are observed throughout the year, and they are the morphological expression of the permanent sand supply. The beach ridges located in the middle and distal area of the bay have dunes at their highest points.

Consequently, it can be noted that from the Middle Holocene to the present deposits of coastal sediments in Tongoy Bay, have formed by accretional sequences of beach ridges, as well as current developing foredunes which have established an evolutionary trend of progressive accretion of the barrier.

\section{Acknowledgement}

\section{FONDECYT Project N 1120234}

\section{References}

1. Bird E (2008) Coastal Geomorphology: An Introduction. In: ( $\left.2^{\text {nd }} e d n\right)$, Chichester: John Wiley and Sons, p. 411.

2. Schwartz ML (2005) Encyclopedia of coastal science. In: Schwartz, Maurice [Ed.], Dordrecht, Springer, Netherland, p. 1211.

3. Dillenburg SR, Hesp PH (2009) Geology and Geomorphology of Holocene Coastal Barriers of Brazil. Springer, Berlín, p. 380.
4. Hesp PA, Dillenburg SR, Barboza EG, TomazellI LJ, Ayup-Zouain RN, et al. (2005) Beach ridges, foredunes or transgressive dunefields? Definitions and an examination of the Torres to Tramandaí barrier system, Southern Brazil. Anais da Academia Brasileira de Ciências 77(3): 493-508.

5. Dillenburg SR, Barboza EG, Hesp PA, Rosa MLCC, Angulo RJ, et al. (2014) Discussion: Evidences for a transgressive barrier within a regressive strandplain system: Implications for complex responses to environmental changes, by Hein et al. (2013), Sedimentology, 60, 469602 A transgressive barrier at Pinheira, Southern Brazil around $3 \mathrm{ka}$ ? Sedimentology, 61(7): 2205-2212.

6. Araya-Vergara JF (1986) Cambios actuales en la línea litoral en Chile central sur. Revista Geográfica de Chile Terra Australis 29: 23-28.

7. Vargas I (1991) Interacción Oleaje-Playas-Dunas en Rocas de Santo Domingo. Santiago, Chile: Universidad de Chile, Dissertation, p.95.

8. Otvos EG (2000) Beach ridges- definitions and significance. Geomorphology 32(1-2): 83-108.

9. Marquardt C, Lavenu A, Portlieb L, Godoy, E, Comte D, et al. (2004) Coastal neotectonics in southern central Andes: uplift and deformation of marine terraces in northern Chile (27 $\mathrm{S})$. Tectonophysics, 394(3-4): 193-219.

10. Quezada J, González G, Dunai T, Jensen A, Juez-Larré J, et al. (2007) Alzamiento litoral pleistocénico del norte de Chile. Edades 21NE de la terraza costera más alta del área de Caldera-Bahía Inglesa. Revista Geológica de Chile 34(1): 81-96.

11. Creixell T, Ortiz L, Arévalo C (2012) Geología del Área Carrizalillo - El Tofo. Santiago, Chile: Servicio Nacional de Geología y Minería. Mapa Geológico, № 133 y 134, escala 1:100.000.

12. Paskoff R (1970) Recherches Geomorphologiques dans le Chili semiaride. Bordeaux: Biscaye Frères, p. 420.

13. Ota Y, Paskoff R (1993) Holocene deposits on the coastal of northcentral Chile: Radiocarbon ages and implications for coastal changes. Revista Geológica de Chile 20(1): 25-32.

14. Emparán C, Pineda G (2006) Geología del área Andacollo Puerto Aldea. Región de Coquimbo: Escala 1: 100.000. Santiago: Servicio Nacional de Geología y Minería, Chile 96: 85.

15. Le Roux JP, Olivares DM, Nielsen SN, Smith ND, Middleton H, et al (2006) Bay sedimentation as controlled by regional crustal behavoiur, local tectonics and eustatics sea-level changes: Coquimbo Fomation (Mioceno-Plioceno), Bay of Tongoy, central Chile. Sedimentary Geology 184(1-2): 133-153.

16. Pfeiffer M (2011) Evolución y Génesis de Calcretas Pedogénicas en la Paleobahía de Tongoy. Santiago, Chile: Universidad de Chile, Master's thesis, Chile, p. 175.

17. Saillard M, Hall SR, Audin L, Fraber DL, Herail G, et al. (2009) Non-steady long-term uplift rates and Pleistocene marine terrace development along the Andean margin of Chile $\left(31^{\circ} \mathrm{S}\right)$ inferred from $10 \mathrm{Be}$ dating. Earth and Planetary Sciences Letters 277(1-2): 50-63.

18. Saillard M, Riotte J, Regards V, Viollete A, Hérail G, et al. (2012) Beach ridges UeTH dathing in Tongoy bay tectonic implications for a peninsula bay system, Chile. Journal of South American Earth Science 40: 77-84.

19. Pérez C (2005) Cambio Climático: Vulnerabilidad, Adaptación y Rol Institucional. Estudio de Casos en el Valle del Elqui. La Serena, Chile: Universidad de La Serena, Dissertation, p. 203.

20. Aceituno P (1998) El Fenómeno EL Niño 1997-1998. Bulletin de l'Institut Français d'Études Andines 27(3): 443-448.

21. Pérez C, Fiebig-Wittmaack M, Cepeda-Pizarro J, Pizarro-Araya J (2009) Desastres naturales y plagas en el valle del Río Elqui. In: CepedaPizarro J [Ed.], Los Sistemas Naturales de la Cuenca del Río Elqui (Región de Coquimbo, Chile): Vulnerabilidad y Cambio del Clima. La 


\section{Recent Advances in Petrochemical Science}

Serena: Ediciones Universidad de La Serena, Chile, pp. 315-353.

22. Uribe E, Blanco JL (2001) Capacidad de los sistemas acuáticos para el sostenimiento del cultivo de pectínidos: El caso de Argopecten purpuratus en la Bahía Tongoy, Chile. In: Maeda-Martínez AN [Ed.]. Los Moluscos Pectínidos de Iberoamérica: Ciencia y Acuicultura. Mexico, DF: Limusa SA, pp. 233-248.

23. Berrios M (2005) Características hidrográficas de Bahía Tongoy y zona de influencia de proyecto. Proyecto Abalon "Pachingo-Live Sea Food". La Serena: Universidad Católica del Norte, p. 100.

24. Hesp PA (2004) Sand beach ridges: Definitions and re-definitions Journal of Coastal Research 39: 72-75.

25. Arriagada J (2009) Geomorfología Estuarial Comparada en la Zona Semiárida de Chile. Casos de Copiapó y Choapa. Santiago, Chile: Universidad de Chile, Master's thesis, chile, p. 100.

26. Verstappen H (1972) On dune types, familias and sequences in areas of unidirectional winds. Göttinger Geographische Abhandlungen 60: 341-353.

27. Soto MV, Märker M, Rodolfi G, Sepúlveda AS, Cabello M, et al. (2014) Assessment of geomorphic processes affecting the paleo-landscape of Tongoy bay, Coquimbo region, central Chile. Geografia Fisica e Dinamica Quaternaria, 37(1): 51-66.

28. Soto MV, Sarricolea P, Sepúlveda SA, Rodolfi G, Cabello M, et al. (2017) Assessment of hydro-geomorphological hazard potentials in the Chilean semiarid coastal range and its impacts on La Serena city, Coquimbo Region. Natural Hazards 88(1): 431-452.

29. Lagos G (2013) Caracterización Geomorfológica y Dinámica Costera de Bahías del Semiárido de Chile. Casos de Estudio: Bahía de Tongoy y Bahía Barnes, Región de Coquimbo. Santiago, Chile: Universidad de Chile, Dissertation, Chile, p. 85.

30. Villagrán C (2007) Dinámica Costera en el Sistema de Bahías Comprendidas entre Ensenada Los Choros y Bahía de Tongoy. Santiago, Chile: Universidad de Chile, Dissertation, p. 120.

31. Encinas A, Hervé F, Villa-Martínez R, Nielsen S, Finger K, et al. (2006) Finding of a Holocene marine layer in Algarrobo ( $\left.33^{\circ} 22^{\prime} \mathrm{S}\right)$, central Chile. Implications for coastal uplift. Revista Geológica de Chile, 33(2) 339-345.
32. Araya-Vergara JF (1996) Sistema de interacción oleaje-playa frente a los ergs de Chanco y Arauco, Chile. Gayana Oceanológica 4(2): 159-167.

33. Arriagada J, Soto MV, Sarricolea P (2014) Morphodynamic environment in a semiarid mouth river complex. Choapa River, Chile. In: Marghany M [Ed], Advanced Geociences Remote Sensing. Rijeka, Croatia: Intech, pp. 253-271.

34. Martínez C (2001) El Efecto de Ensenada en los Procesos Litorales de las Ensenadas de Valparaíso, Algarrobo y Cartagena, Chile. Santiago, Chile: Universidad de Chile, Master's thesis, Chile, p.152.

35. Soto MV (2005) Aspectos morfodinámicos de ensenadas desalineadas del litoral de Chile central: Pichilemu y caleta Los Piures. Revista de Geografía Norte Grande 33: 73-87.

36. Soto MV, Arriagada J (2007) Características dinámicas de ensenadas estructurales de Chile central. Maitencillo-Cachagua y Papudo, Región de Valparaíso. Revista de Geografía Norte Grande 38: 99-112.

37. Soto MV, Arriagada J, Castro CP, Ibarra I, Rodolfi G, et al. (2015) Condiciones geodinámicas derivadas del terremoto y tsunami de 2010 en la costa de Chile central. El caso de Pichilemu. Revista de Geografía Norte Grande 60: 79-95.

38. Tamura T (2012) Beach ridges and prograded beach deposits as paleoenvironment records. Earth Science Review 114(3-4): 279-297.

39. Nielsen L, Bendixen M, Kroon A, Hede MU, Clemmensen LB, et al. (2017) Sea-level proxies in Holocene raised beach ridge deposits (Greenland) revealed by ground-penetrating radar. Scientific Reports 7: 46460.

40. Pfeiffer M, Le Roux JP, Solleiro-Rebolledo E, Kemmitz H, Sedov $S$, et al. (2011) Preservation of beach ridges due to pedogenic calcrete development in the Tongoy Paleo Bay, Noth-central Chile. Geomorphology 132: 234-248.

41. Short AD (1999) Waves-dominated beachs. In: Short A [Ed.]. Handbook of beach and shoreface morphodynamics, Chichester: Wiley and Sons, pp. 173-191.

42. Tricart J (1960) Los tipos de lechos fluviales. Revista Geográfica Universidad de los Andes 2: 5-6.

43. Wright LD, Short AD (1984) Morphodynamic variability of surf zone and beaches: A synthesis. Marine Geology, 56(1-4): 93-118.

44. Dirección Meteorológica de Chile.

Your next submission with Juniper Publishers will reach you the below assets

- Quality Editorial service

- Swift Peer Review

- Reprints availability

- E-prints Service

- Manuscript Podcast for convenient understanding

- Global attainment for your research

- Manuscript accessibility in different formats

( Pdf, E-pub, Full Text, Audio)

- Unceasing customer service

Track the below URL for one-step submission https://juniperpublishers.com/online-submission.php 